\title{
Spatial diversity of planktonic protists in the Lagoon of Venice (LTER-Italy) based on 18S rDNA
}

\author{
Simona Armeli Minicante, ${ }^{1}$ Roberta Piredda, ${ }^{2}$ Stefania Finotto, ${ }^{1}$ Fabrizio Bernardi Aubry, ${ }^{1 *}$ Francesco Acri, ${ }^{1}$ \\ Alessandra Pugnetti, ${ }^{1}$ Adriana Zingone ${ }^{2}$ \\ ${ }^{1}$ Institute of Marine Sciences, National Research Council (ISMAR-CNR), Venice; ${ }^{2}$ Department of Integrative Marine Ecology, Stazione \\ Zoologica Anton Dohrn, Naples, Italy
}

\begin{abstract}
Transitional waters are subject to a high degree of variability in space and time. In this study, protist plankton communities of the Lagoon of Venice were compared among four sites characterised by different environmental conditions with a metabarcoding approach. High throughput sequencing (HTS) of the V4-18S rDNA fragment in 32 samples collected on four dates, from April 2016 to February 2017, produced 1,137,113 reads, which were grouped into 4058 OTUs at 97\% similarity. Bacillariophyta and Ciliophora were the most abundant groups in the entire dataset in terms of read number ( $27.6 \%$ and $16.6 \%$, respectively), followed by Dinophyta (10.9\%), Cryptophyceae $(9.7 \%)$, and Syndiniales $(6.1 \%)$. The contribution of protist groups markedly varied across the seasons, but spatial differences were also recorded in the lagoon. In April, a higher contribution of Bacillariophyta characterized St1 and 5 (68.0\% and 61.1\%), whereas Sts2 and 3 showed a higher percentage of Ciliophora (18.6 and $23.4 \%$, respectively) and dinoflagellates (10.3 and 7.7\%). In July, diatom blooms occurred at Sts1, 2 and 3, with some differences in the dominant species. At St2 Dinophyta reached the highest contribution of the whole sampling period in the area (30.6\%), while St5 was quite distinct, with a low contribution of diatoms and a dominance of Ciliophora (34.0\%) and Trebouxiophyceae (36.4\%). All the stations in November were characterized by relatively high abundance of Ciliophora (21.4-51.9\%). In February, diatom contribution was relevant only at St5 (29.3\%), Teleaulax acuta peaked at St3 (ca. 36\%), Syndiniales at St2 (38.8\%) and Dictyochophyceae at St1 (24.2\%). The $\alpha$-diversity indexes (observed OTUs, Shannon and Pielou evenness) showed a high variability over space and time. Diversity and community composition were rather similar between the intermediate and deeper Sts 2 and 3 on all sampling dates whereas they at time differed between the landward and shallow Sts1 and 5. While the most marked differences occurred over the temporal scale, the depth of the station and the relatedness with the external marine coastal environment appear to play a major role in the spatial distribution of protist communities within the lagoon. Overall, the quite stable spatial differences in spite of the significant seasonal changes reflected the hydro-geological heterogeneity of the sampling stations, indicating a major influence of the landsea gradient in the lagoon.
\end{abstract}

\section{INTRODUCTION}

The search of factors shaping the protistan plankton community has been extended and enhanced in the last years thanks to the combination of molecular data with tools from macroecology. Studies on habitat heterogeneity in different marine ecosystems (Grossmann et al., 2016; Massana et al., 2015; de Vargas et al., 2015; Wu et al., 2020) have shown that plankton microeukaryotes present different community compositions depending both on environmental factors, affecting the habitat features, and on geographical distance on the small scale (Horner-Devine et al., 2004; Martiny et al., 2006; Wu et al., 2020).

Habitat heterogeneity is particularly marked in transitional water ecosystems (TWE; European Union, 2000; Elliot and McLusky, 2002), such as coastal lagoons, due to their geomorphology, the close benthic-pelagic coupling, the freshwater inputs, and the connection with the adjacent marine ecosystems through tides and currents, (Basset et al., 2006; McLusky and Elliot, 2007; Vadrucci et al., 2007). These TWE features have a profound effect on plankton composition and distribution at both spatial and temporal scales (Cloern and Jassby, 2010).

The Lagoon of Venice (LoV) is the largest Italian lagoon. This TWE belongs to the Long Term Ecosystem Re- search (LTER) national (LTER-Italy), European (LTEREurope) and global (ILTER) networks, which are essential components of the worldwide efforts to improve our knowledge of the structure and functions of ecosystems and of their long-term response to environmental, societal, and economic drivers (Mirtl et al., 2018). They are distributed networks of research sites for multiple purposes in the fields of ecosystem, critical zone, and socio-ecological research. LTER-Italy consists of 79 research sites, which include terrestrial, freshwater, transitional and marine ecosystems (Pugnetti et al., 2013; Bergami et al., 2018).

For what concerns planktonic protists of the LoV, past LTER activities addressed almost exclusively phytoplankton communities, for which a consistent knowledge has been gathered through morphology-based studies (Bernardi Aubry et al., 2013, 2017). The LoV community includes taxa that are representative of the complex and open system of the lagoon itself, from the coastal sea to the rivers and the benthic-pelagic system: overall, they show a rather even distribution across distinct lagoon sites, while habitat heterogeneity could barely be detected (Bernardi Aubry et al., 2013). High Throughput Sequencing (HTS) metabarcoding has so far been applied to the LoV bacterial communities (Quero et al., 2017) and, more recently, also to the whole protistan community, in a comparison between 
the lagoon and the adjacent marine waters of the Gulf of Venice (Armeli Minicante et al., 2019). In spite of potential pitfalls of the metabarcoding approach, which can poorly resolve the diversity of some taxa (Piredda et al. 2018) or miss them altogether (Massana et al., 2015), the latter study based on the V4-18S rRNA metabarcodes largely increased the diversity knowledge not only for protists that have traditionally been neglected (i.e., heterotrophs, parasites, picoeukaryotes and other featureless groups), but also for the main phytoplankton taxa studied in the long term with morphology-based approaches (i.e., diatoms and dinoflagellates). In addition, HTS results highlighted profound differences in the structure of the protistan communities between the lagoon and the external coastal waters of the Gulf of Venice: heterogeneity appears strong enough to allow for ecological segregation in the two environments, despite no clear barrier to dispersal processes among local protist communities.

In this study, we explore the effects of habitat heterogeneity within the LoV by comparing protistan communities among four individual LoV sites that were lumped together in the previous HTS study. The main goal of this work is to test whether the overall picture of rather spatially homogeneous LoV communities emerging from morphologically-based studies on phytoplankton is confirmed by the higher resolution and better coverage allowed by the HTS-metabarcoding approach. We aim at assessing if environmental selection plays a more important role than dispersal in shaping the microeukaryotic communities within the LoV and identifying the most relevant local conditions that could affect them.

\section{METHODS}

\section{Study area}

The LoV (Northern Adriatic Sea, Mediterranean Sea) is a microtidal, polyhaline lagoon classified as a transitional water body (European Union, 2000) and is the largest wetland $\left(550 \mathrm{~km}^{2}\right)$ in the Mediterranean Sea (Poggioli, 2008). This delicate and fragile ecosystem is surrounded by densely inhabited and industrial areas and is affected by high numbers of tourists, as well as intensive fisheries and aquaculture activities. It has an average depth of $1 \mathrm{~m}$ and is morphologically characterized by the presence of large shallow areas and a network of deeper $(5-10 \mathrm{~m})$ channels. Three inlets interrupt the sandbars separating the lagoon from the sea, allowing water turnover during tidal cycles, whose amplitude is $100 \mathrm{~cm}$ with maxima of $150 \mathrm{~cm}$. Water residence time, resulting from the interactions of tide, wind and topography, ranges from a few days close to the inlets to one month in landward areas (Umgiesser et al., 2014; Ghezzo et al., 2015). Twelve main tributaries discharge an annual average of about $35 \mathrm{~m}^{3} \mathrm{~s}^{-1}$ of freshwater into the lagoon, with seasonal peaks in spring and autumn. In recent years aquatic angiosperms have recolonized the lagoon, especially in the central and northern basins (Sfriso and Buosi, 2018); however, in large areas the main primary producer is phytoplankton (Acri et al., 2004, Sfriso et al., 2005; Bernardi Aubry et al., 2013).

In this study four sampling campaigns were conducted in April, July, November 2016 and February 2017, respectively, at four stations (St1, St2, St3 and St5, Fig.1) that are regularly sampled for phytoplankton and abiotic factors within LTER activities (Bernardi Aubry et al., 2013). The stations are all influenced, at different extents, by marine and freshwater inputs: St1 (S. Giuliano, $2 \mathrm{~m}$ depth ) is in an area of intense maritime traffic (Bianchi et al. 1996, Socal et al. 1999) which collects urban waste from the town of Mestre; St2 (Marghera, $9.5 \mathrm{~m}$ ) is affected by industrial pollution (Perin 1975, Guerzoni et al. 2007); St 3 (Fusina, $3.5 \mathrm{~m}$ ) is influenced by heat emissions from the Porto Marghera power station (Alberighi et al., 1992, Socal et al., 1999); St5 (Palude della Rosa, depth $2.7 \mathrm{~m}$ ) is a typical inland marshy lagoon area (Bianchi et al., 1999). Differences among the stations mainly depend on the varying degrees of impact of the interactions among the adjacent marine waters, riverine inputs and benthic-pelagic coupling (Bernardi Aubry et al., 2013).

\section{Abiotic parameters}

For each station, temperature and salinity were measured with a CTD SBE 911 probe and water samples were collected at the near-surface layer using a Niskin bottle.

For chlorophyll $a(\mathrm{Chl} a), 500 \mathrm{~mL}$ of water samples were immediately filtered through Whatman GF/F fibreglass filters (nominal porosity $=0.7 \mu \mathrm{m}$ ), which were stored frozen and subsequently analyzed according to Holm-Hansen et al. (1965). Dissolved Inorganic Nitrogen (DIN), as sum of ammonium $\left(\mathrm{N}-\mathrm{NH}_{4}\right)$, nitrites $\left(\mathrm{N}^{\left.-\mathrm{NO}_{2}\right)}\right.$ and nitrates $\left(\mathrm{N}-\mathrm{NO}_{3}\right)$, was analyzed along with orthophosphates (P-PO4) and orthosilicates ( $\mathrm{Si}-\mathrm{SiO} 4)$ with a Systea EasyChem Plus according to Grasshoff et al. (1983).

\section{Filtration, DNA extraction and sequencing}

At each station, $3 \mathrm{~L}$ of seawater were prefiltered on a $200 \mu \mathrm{m}$ mesh-size net and then filtered onto cellulose ester $1.2 \mu \mathrm{m}$ pore size filters ( $47 \mathrm{~mm} \varnothing$, Whatman) using a peristaltic pump. For each station a duplicate was performed, obtaining 32 filters that were stored at $-80^{\circ} \mathrm{C}$ until molecular analysis. Total DNA from each filter was extracted using the DNeasy 96 Plant Kit (QIAGEN) and concentrations were determined with the Qubit dsDNA HS kit (Thermofisher). DNA samples were stored at $-80^{\circ} \mathrm{C}$ until PCR. The hypervariable V4 region of eukary- 
ote SSU rDNA gene was amplified and sequenced ( $2 \mathrm{X}$ $250 \mathrm{bp}$ sequencing) on an Illumina MiSeq platform as described in Piredda et al. (2017).

\section{Sequence analyses}

Paired-end reads were processed using Mothur v.1.33.0 (Schloss et al., 2009). Contigs between read pairs were assembled and differences in base calls in the overlapping region were solved using $\Delta \mathrm{Q}$ parameter as described in Kozich et al. (2013). Primer sequences were removed (pdiffs $=3$ ) and no ambiguous bases were allowed; the maximum homopolymer size was $8 \mathrm{bp}$. The remaining sequences were de-replicated and screened for chimeras using UCHIME in de novo mode (Edgar et al., 2011). Sequences were clustered into operational taxonomic units (OTUs) at $97 \%$ of similarity using vsearch (Rognes et al., 2016) clustering (method=dgc) through mothur. OTUs containing only one read (singleton) were removed from downstream analyses. Taxonomic assignment was performed on a single representative sequence from each OTU (the most abundant) using BLASTN (Altschul et al., 1990) against the PR2 database (v.4.10.0; https://doi.org/10.6084/m9. figshare.5913181; Guillou et al., 2013), discarding the assignations with similarity $\leq 90 \%$ and query coverage $\leq 70 \%$ of the sequence length.

\section{Statistical analyses}

The vegan R package (R Core Team, 2014; Oksanen et al., 2016) was used for multivariate analyses.

The dataset was normalized with a random subsampling to the second-lowest number of sequences $(\mathrm{n}=$ 74,396) with the 'rrarefy' function.

Observed OTUs and $\alpha$-diversity estimators (Shannon diversity and Pielou evenness) were calculated and Non-metric multidimensional scaling (NMDS) was performed using the 'metaMDS' function (vegan) based on a Bray-Curtis dissimilarity matrix. PerMANOVA (adonis function in vegan) was used to detect significant association between environmental parameters and protist community structure. The selected variables were used to perform Canonical Correspondence Analysis (CCA).

\section{RESULTS}

\section{Abiotic parameters and chlorophyll $a$}

Abiotic parameters and Chl $a$ showed a wide variability over time and among stations (Tab. 1). Salinity values (21-32.3) most of the times were lowest at Sts1 and 5 ( $>21$ and 23, respectively), while they were above 30 all year round at the other two stations. Temperature ranged between $9.4^{\circ} \mathrm{C}\left(\mathrm{St} 2\right.$, February) and $31.5^{\circ} \mathrm{C}(\mathrm{St} 3$, July), with
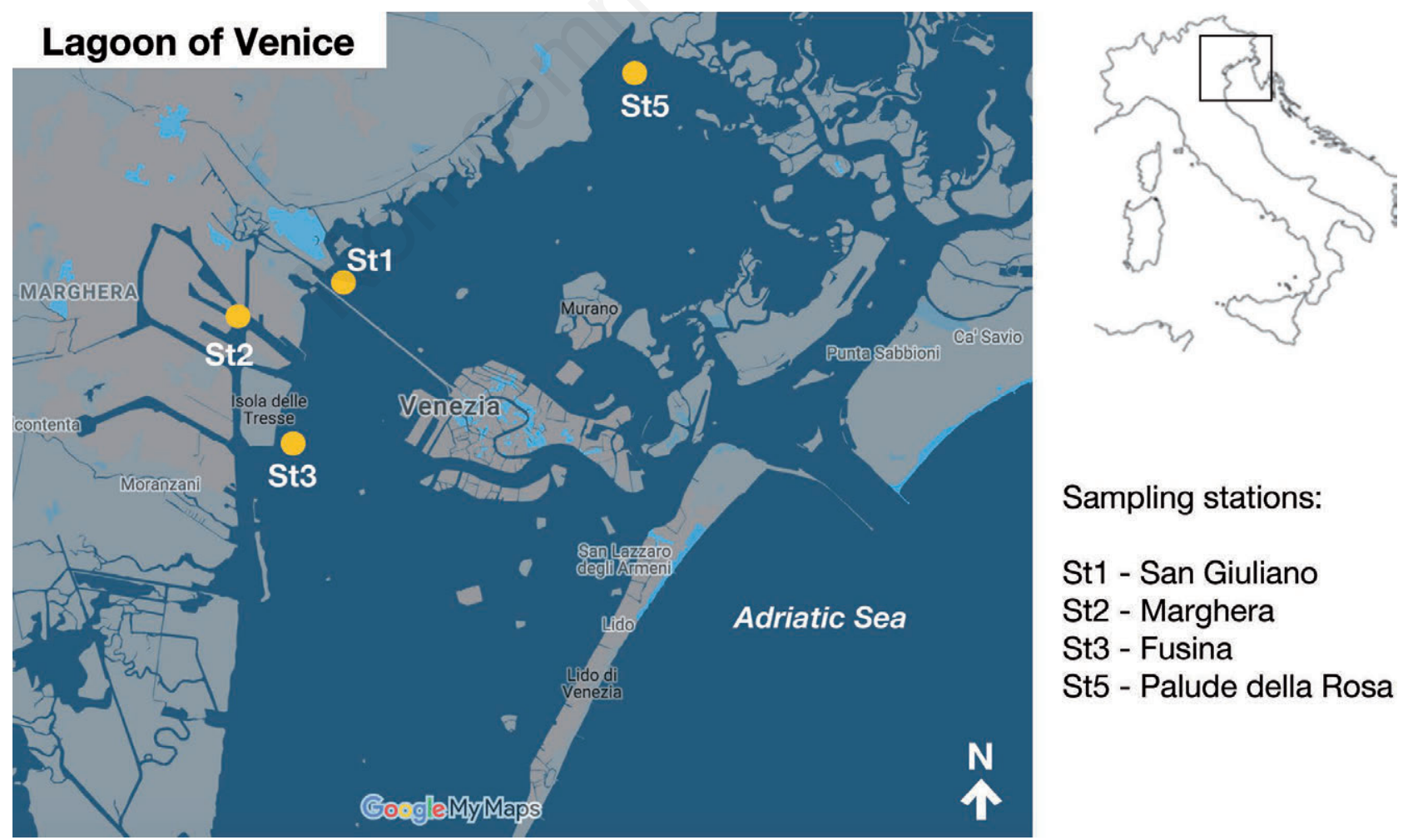

\section{Sampling stations:}

St1 - San Giuliano

St2 - Marghera

St3 - Fusina

St5 - Palude della Rosa

Fig. 1. Study area with the four sampling stations. 
marked differences $\left(6-10^{\circ} \mathrm{C}\right)$ among stations on the same sampling date, and $\mathrm{St} 3$ always showing the highest values. DIN and silicate concentrations peaked at all the stations, and particularly at Sts1 and 5, in November (25.4-88.1 $\mu \mathrm{M})$ and February (9.1-61.7 $\mu \mathrm{M})$, the maxima occurred mostly at St1 in every date. Phosphates were always highest at St1 (0.6-3 $\mu \mathrm{M})$, while at the other stations they fluctuated between 0,1 and $1.1 \mu \mathrm{M}$ without a clear seasonal or spatial pattern. Chl $a$ concentrations were higher at Sts1 and 5 (2.7 and $2.2 \mu \mathrm{gL}^{-1}$, respectively) in April, then they peaked in July at Sts 1,2 and 5 (12.6, 11.8 and $9.6 \mu \mathrm{gL}^{-1}$, respectively) and were relatively low at all stations in November (0.2$\left.0.7 \mu \mathrm{gl}^{-1}\right)$ and February $\left(0.1-0.7 \mu \mathrm{gL}^{-1}\right)$. The highest Chl $a$ concentrations were recorded at St 1 on all dates but February, when the maximum was at St5.

\section{Protist diversity and seasonality}

The total cleaned dataset contained 3,588,416 reads from 32 samples. Duplicate samples were generally coupled in hierarchical clustering based on Bray-Curtis distance (data not shown) and were hence pooled into 16 samples. After the normalization, the dataset consisted of 1,137,113 V4-18S reads (Supplementary Material 1), clustering into 4,058 OTUs mostly belonging to 34 highlevel taxonomic groups (Fig. 2).

Bacillariophyta and Ciliophora were the most abundant groups in terms of read number $(27.6 \%$ and $16.6 \%$, respectively), followed by Dinophyta (10.9\%), Cryptophyceae (9.7\%), Syndiniales (6.1\%). Chrysophyceae, Dictyochophyceae, Mamiellophyceae, Trebouxiophyceae, MAST (nanoheterotrophic marine stramenopiles) and Chlorophyceae ranged between 2 and $5 \%$. The remaining 23 taxonomic groups were included in "other Eukaryotes" (8.9\%).
Over the four sampling dates, a change in the proportion of the main groups was evident at all stations, which at times also differed among them (Fig. 3). Common to Sts 1, 2 and 3 was the high relative abundance of Bacillariophyta both in April (max 67.9\%, at St1) and July (max $87 \%$, at St3) and their very low abundance in November $(1.1 \%$, at St2) and February (1.9\%, at St2). At St5, Bacil-

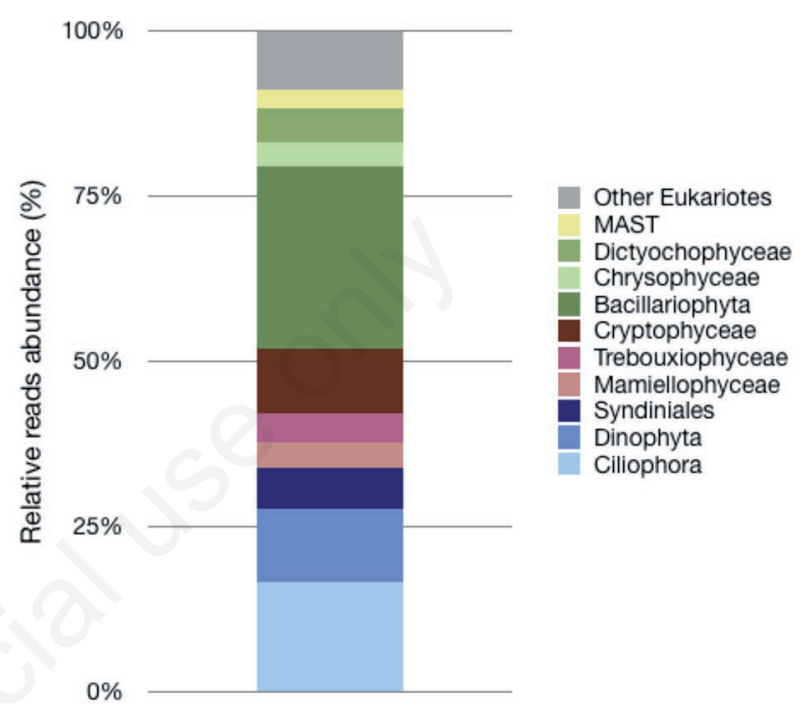

Fig. 2. Taxonomic diversity of the normalized dataset as percentage of reads belonging to the main 10 high-level taxonomic groups and to the broad group "Other Eukaryotes" which includes: Apusozoa, Radiozoa, Amoebozoa, Stramenopiles, Apicomplexa, Perkinsea, Palagophyceae, Bolidophyceae, Telonemia, Pirsonia, Bicoecea, MOCH, Prymnesiophyceae, Centroheliozoa, Katablepharidaceae, Choanoflagellatea, Labyrinthulea, Prasinophyceae, Oomycota, Chlorodendrophyceae, Chlorophyceae, Cercozoa, Rhodophyta, Picozoa.

Tab. 1. Environmental variables at the four stations of the Lagoon of Venice investigated on four sampling dates.

\begin{tabular}{|c|c|c|c|c|c|c|c|}
\hline Month & Station & $\begin{array}{c}\text { Temperature } \\
\left({ }^{\circ} \mathrm{C}\right)\end{array}$ & Salinity & $\begin{array}{l}\text { DIN } \\
(\mu \mathrm{M})\end{array}$ & $\begin{array}{c}\mathrm{Si}^{-\mathrm{SiO}_{4}} \\
(\mu \mathrm{M})\end{array}$ & $\begin{array}{c}\mathrm{P}^{-\mathrm{PO}_{4}} \\
(\mu \mathrm{M})\end{array}$ & $\begin{array}{r}\text { Chl-a } \\
\left(\mu \mathrm{gL}^{-1}\right)\end{array}$ \\
\hline April & $\begin{array}{l}\text { ST1 } \\
\text { ST2 } \\
\text { ST3 } \\
\text { ST5 }\end{array}$ & $\begin{array}{l}14.1 \\
17.3 \\
24.3 \\
14.1\end{array}$ & $\begin{array}{l}20.9 \\
30.1 \\
29.5 \\
30.3\end{array}$ & $\begin{array}{l}30.3 \\
17.9 \\
23.1 \\
13.9\end{array}$ & $\begin{array}{l}36.7 \\
13.1 \\
18.3 \\
10.8\end{array}$ & $\begin{array}{l}0.5 \\
0.5 \\
0.3 \\
0.1\end{array}$ & $\begin{array}{l}2.7 \\
0.8 \\
0.1 \\
2.2\end{array}$ \\
\hline July & $\begin{array}{l}\text { ST1 } \\
\text { ST2 } \\
\text { ST3 } \\
\text { ST5 }\end{array}$ & $\begin{array}{l}25.3 \\
28.8 \\
31.5 \\
25.5\end{array}$ & $\begin{array}{l}29.5 \\
31.3 \\
30.0 \\
27.1\end{array}$ & $\begin{array}{c}15.2 \\
6.5 \\
17.5 \\
12.3\end{array}$ & $\begin{array}{l}41.6 \\
13.6 \\
16.6 \\
43.8\end{array}$ & $\begin{array}{l}2.3 \\
0.2 \\
1.2 \\
0.6\end{array}$ & $\begin{array}{c}12.5 \\
11.7 \\
1.7 \\
9.5\end{array}$ \\
\hline November & $\begin{array}{l}\text { ST1 } \\
\text { ST2 } \\
\text { ST3 } \\
\text { ST5 }\end{array}$ & $\begin{array}{l}14.5 \\
14.7 \\
22.1 \\
14.0\end{array}$ & $\begin{array}{l}28.3 \\
31.0 \\
31.6 \\
25.9\end{array}$ & $\begin{array}{l}83.9 \\
36.9 \\
36.0 \\
63.8\end{array}$ & $\begin{array}{l}88.1 \\
28.4 \\
25.3 \\
37.2\end{array}$ & $\begin{array}{l}2.5 \\
1.0 \\
0.8 \\
0.4\end{array}$ & $\begin{array}{l}0.7 \\
0.3 \\
0.2 \\
0.5\end{array}$ \\
\hline February & $\begin{array}{l}\text { ST1 } \\
\text { ST2 } \\
\text { ST3 } \\
\text { ST5 }\end{array}$ & $\begin{array}{c}10.4 \\
9.4 \\
15.6 \\
11.8\end{array}$ & $\begin{array}{l}21.0 \\
31.3 \\
32.9 \\
23.3\end{array}$ & $\begin{array}{l}75.8 \\
53.8 \\
27.4 \\
24.4\end{array}$ & $\begin{array}{c}61.6 \\
27.1 \\
12.7 \\
9.1\end{array}$ & $\begin{array}{l}2.9 \\
0.7 \\
0.4 \\
0.2\end{array}$ & $\begin{array}{l}0.5 \\
0.1 \\
0.5 \\
0.7\end{array}$ \\
\hline
\end{tabular}


lariophyta contribution was highest in April (61.1\%) too, but low in July (10.9\%) and relatively high again in February (29.3\%). Other seasonal patterns shared among stations concerned the higher contribution of Trebouxiophyceae in July (up to $23.6 \%$ and $536.4 \%$ at Sts 1 and 5, respectively), of Ciliophora at all stations in November (21.3-51.9\%), and the low contribution of Cryptophyceae and Mamiellophyceae in July. Besides, at all stations Dictyochophyceae were more abundant at almost all stations in February $(<24.1 \%$ at St1), while the contribution of Chrysophyceae was significant in November, especially at St5 (12.9\%). Dinophyta attained more than the $20 \%$ of the total abundance only at St2 in July (30.6\%) and November (23.7\%).

Within each sampling date, some dissimilarities among stations were also evident. In April, the main difference was the highest contribution of Bacillariophyta at Sts 1 and 5, which also showed the highest Chl $a$ concentrations. Yet, diatom species composition differed between these two stations: Thalassiosira concaviuscula dominated both the group and the whole protist assemblage at St1 (56.6\% of total reads), while it covered less than $1 \%$ at St5, where the dominant species (50\%) was Cyclotella sp. At the other two stations, diatoms were less abundant and mainly represented by Thalassiosira spp., Chaetoceros tenuissimus, Navicula and Skeletonema. Sts 2 and 3 differed from Sts1 and 5 also for the highest abundance of Ciliophora (18.6\% and $23.4 \%$ ), mainly represented by Strombidida and by the tintinnid Tintinnopsis, and of dinoflagellates $(<10 \%)$, with the autotrophic species
Gymnodinium dorsalisulcum and Heterocapsa pygmaea. Mamiellophyceae, mainly Ostreococcus mediterraneus, were most abundant at St3 (10.9\%), Cryptophyceae at St2 (15.0\%) with Teleaulax acuta and Rhodomonas sp.

In July a diatom bloom occurred at Sts 1, 2 and 3, with the highest relative percentage contribution $(87.5 \%)$ at St. 3 and the lowest (50.7\%) at St1. Chaetoceros tenuissimus dominated at Sts 1 and 3, the cymatosiracean Minutocellus polymorphus at St2. There, Dinophyta, with $G$. dorsalisulcum and $H$. pygmaea $(92.0 \%)$, attained the highest contribution $(30.6 \%)$ of the whole sampling period. St5 was quite distinct from the others due to a much lower percentage of diatoms $(10.9 \%)$ and the dominance of Ciliophora (34\%, mainly Parastrombidinopsis sp.) and Trebouxiophyceae (36.4\%), the latter mainly represented by the green coccoid Picochlorum which was also abundant at St1 (23.6\%).

In November all the stations were characterized by the high abundance and diversity of Ciliophora (21.3$51.9 \%$ ), among which the most abundant were an unknown Strobilidiidae, Rimostrombidium and Strombidium. In addition to Ciliophora, Sts 2 and 3 showed a quite similar composition in terms of both groups and species, with a high proportion of Dinophyta (23.7\% at St2, 15.1\% at St3), mainly represented by $H$. pygmaea, the parasitic group Syndiniales (13.3 at St2, $16.1 \%$ at St3), heterotrophs, such as MAST (6.7\% at St2, $4.4 \%$ at St 3 ) and other eukaryotes (such as Picozoa and other non-photosynthetic stramenopiles, $8.9 \%$ and $9.3 \%$

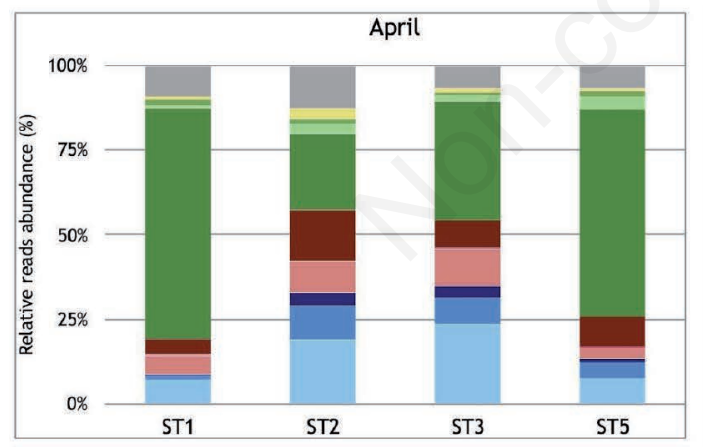

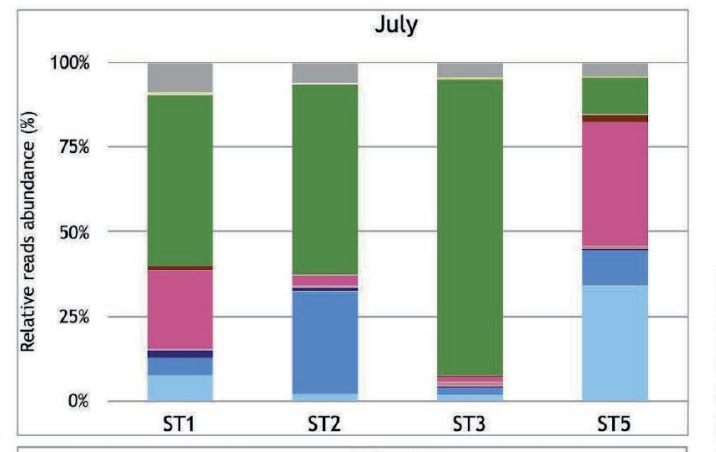

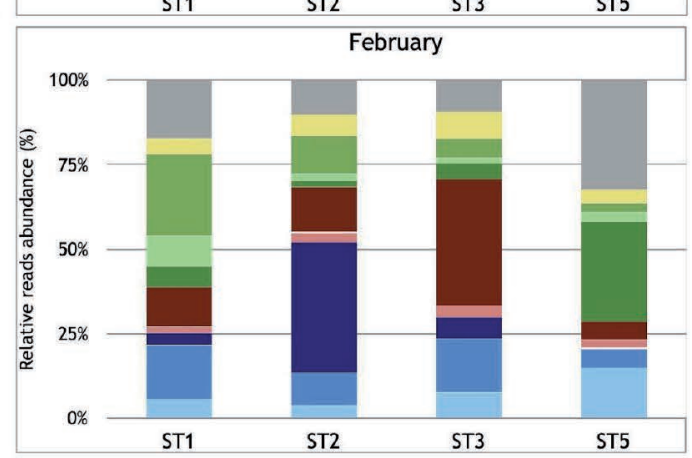

Other Eukariotes MAST

Dictyochophyceae Chrisophyceae Bacillariophyta Cryptophyceae Trebouxiophyceae Mamiellophyceae Syndiniales Dinophyta Ciliophora

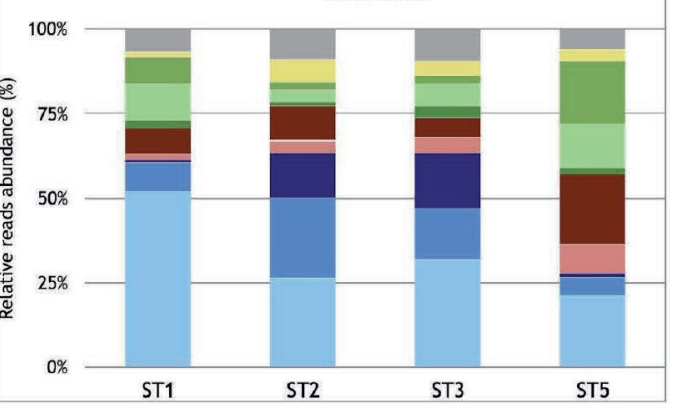

Fig. 3. Composition of the protist community at the four stations at each sampling date, based on the normalized dataset. 
at Sts 2 and 3, respectively ). Cryptophyceae (with a high proportion of Teleaulax acuta) peaked at St5 (20.5\%) together with the Dictyochophyceae Pedinellales (18.7\%).

In February St5 differed from all the others for the dominance of diatoms $(29.3 \%)$ mainly represented by benthic taxa, either marine (Undatella and Achnantes) or freshwater (Cymbella), a higher percentage of ciliates (15.0\%) and the unicellular Rhodophyta (Rhodella sp.) as the most abundant taxon (10.9\%). The dominance of Teleaulax acuta was remarkable at St3 (36\%), while Syndiniales were abundant at St2 (38.8 \%) and Dictyochophyceae at St1 (24.2\%, mainly Apedinella radians). Dinophyceae at St2 and St3 were mainly represented by $H$. pygmaea.

Trends of alpha diversity (Fig. 4) showed a great variability at both time and space scales. The effect of the diatom blooms was more evident in July, resulting in the lowest diversity values particularly at Sts 2 and 3. In February, observed OTU number was the lowest at St5, which however showed the highest evenness value. Overall, diversity indexes were often similar within the two couples of stations, St1-St5 and St2-St3.

The NMDS ordination highlighted a relatively regular pattern in relation to the spatial and temporal scales (Fig. 5). NMDS2 values below or above zero split Sts2 and 3 (bottom of the plot) from Sts1 and 5 (top), whereas NMDS1 separated February and November communities (to the left) from April and July ones (to the right), the lat- ter being the most peculiar ones at all four sites. Sts 2 and 3 were strictly coupled in all sampling events but July, whereas Sts 1 and 5 were slightly more distant but still coupled in all sampling but February.

PerMANOVA selected three environmental variables significantly correlated with the community composition: DIN, salinity, and temperature. In the CCA (Fig. 6) performed using these variables, the first two canonical axes only explained $23 \%$ of the total variance. Yet, the analysis confirmed the clear separation of the July community, which showed a high correlation with temperature. February and November communities were associated with high DIN values. Sts 2 and 3 were coupled in all seasons, although at times more distant than in the NMDS, whereas Sts 1 or 5 were often closer to one of the other two stations than between them.

\section{DISCUSSION}

High spatial and temporal variability is the hallmark for coastal environments and especially in TWEs, which are sensitive to an array of external drivers and pressures. In particular, in the LoV the low average depth causes an accelerated exchange and biogeochemical cycling between the sediments and the water column (Solidoro et al., 2010), which interacts with the variable
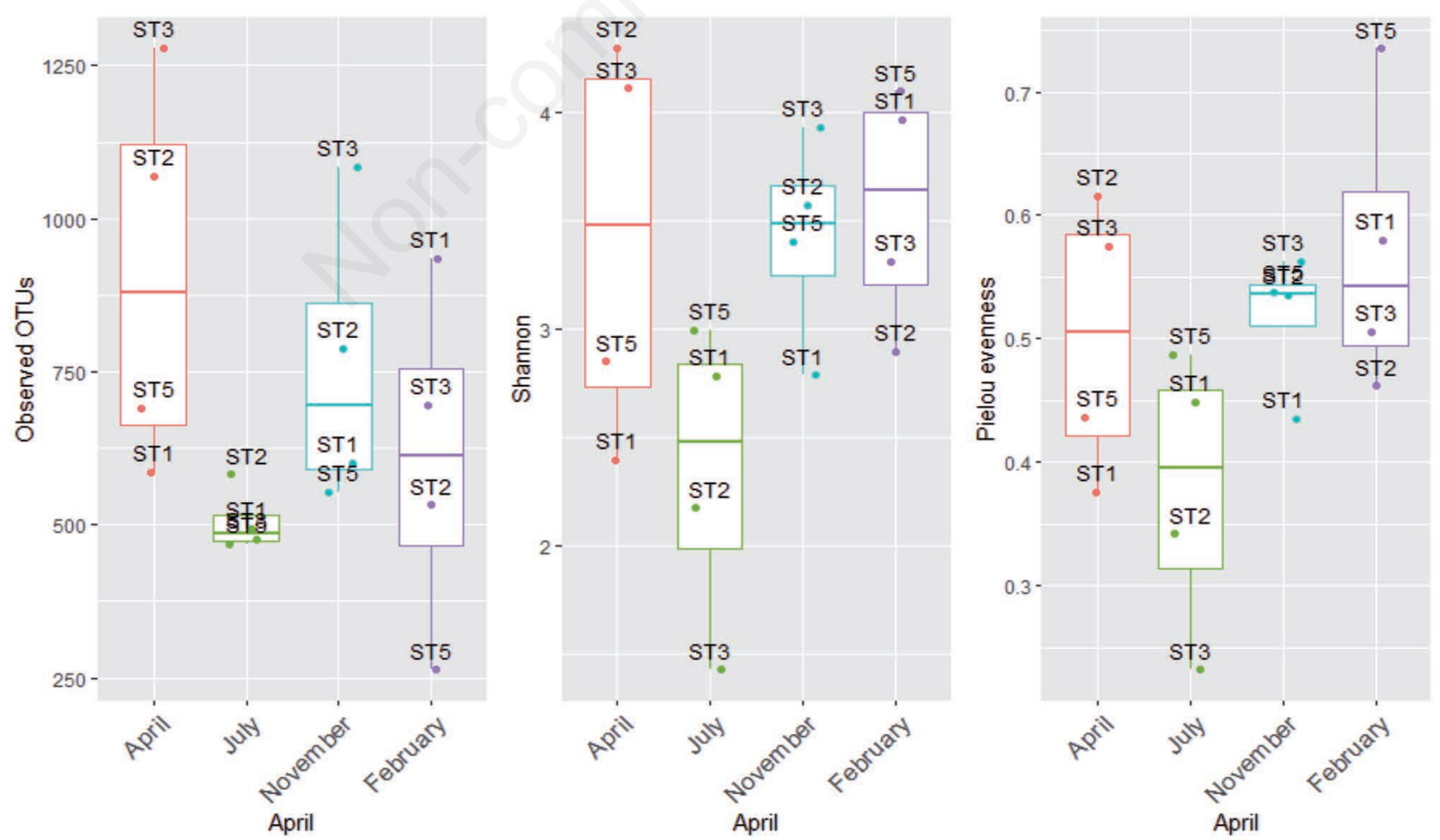

Fig. 4. Trend of $\alpha$-diversity indexes: observed OTUs, Shannon diversity and Pielou evenness. 
nutrient load from land, tide cycle and meteo-climatic-driven hydrodynamism producing a complex space-time dynamic. To date the extent to which this complexity is reflected in the microbial community of the lagoon has only partially been understood also because of the limited resolution and partial coverage of the microbial diversity permitted by classical, microscopy-based approaches. In this study, the V4 -18S rRNA metabarcode analysis allowed a deeper and more complete assessment of microeukariote communities of the area.

Although based on only four time points, the conditions recorded in this study can be considered quite indicative of the four seasons as they emerge from the previous knowledge of the area. The low plankton abundance during the autumn-winter time, the vegetative recovery in winter-spring and the summer peak match the "typical" seasonal trend observed for phytoplankton communities during 10 years of observations in the LoV (Bernardi Aubry et al., 2013). The dominance of Bacillariophyta in summer (and, of lesser importance, in spring) and their low contribution in autumn-winter, when our sampling may have missed the typical Skeletonema peak, are also confirmed by light microscopy analysis (data not shown). While the dominance of tiny Chaetoceros in spring-summer period was already known in the area (Bernardi Aubry et al., 2013), the importance of the cymatosyracean Minutocellus polymorphus at $\mathrm{St} 3$ was not recognized before. The highest contribution of Dinophyta in summer was already reported in literature but with lower abundance (average 2\%; Bernardi Aubry et al., 2013). However, dinoflagellate abundance can be overestimated by HTS studies because of the large amount of multicopy genes (Piredda et al., 2017; Gong et al., 2019). Several species commonly found as abundant or featuring different seasons in this study were also reported as characterizing in others lagoons or estuarine environments,

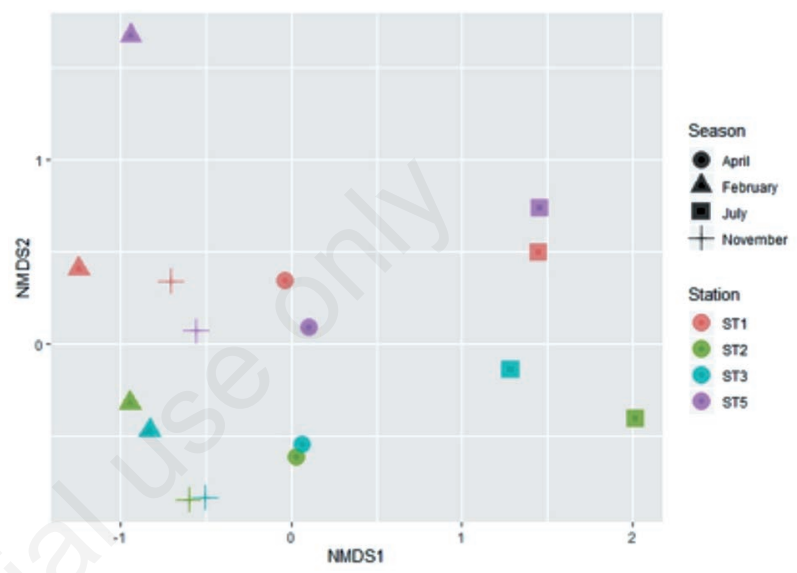

Fig. 5. Non-metric MDS ordination of protist community composition at the four stations, based on the Bray-Curtis dissimilarity matrix calculated on the OTU table. Stress value $=0.099$.

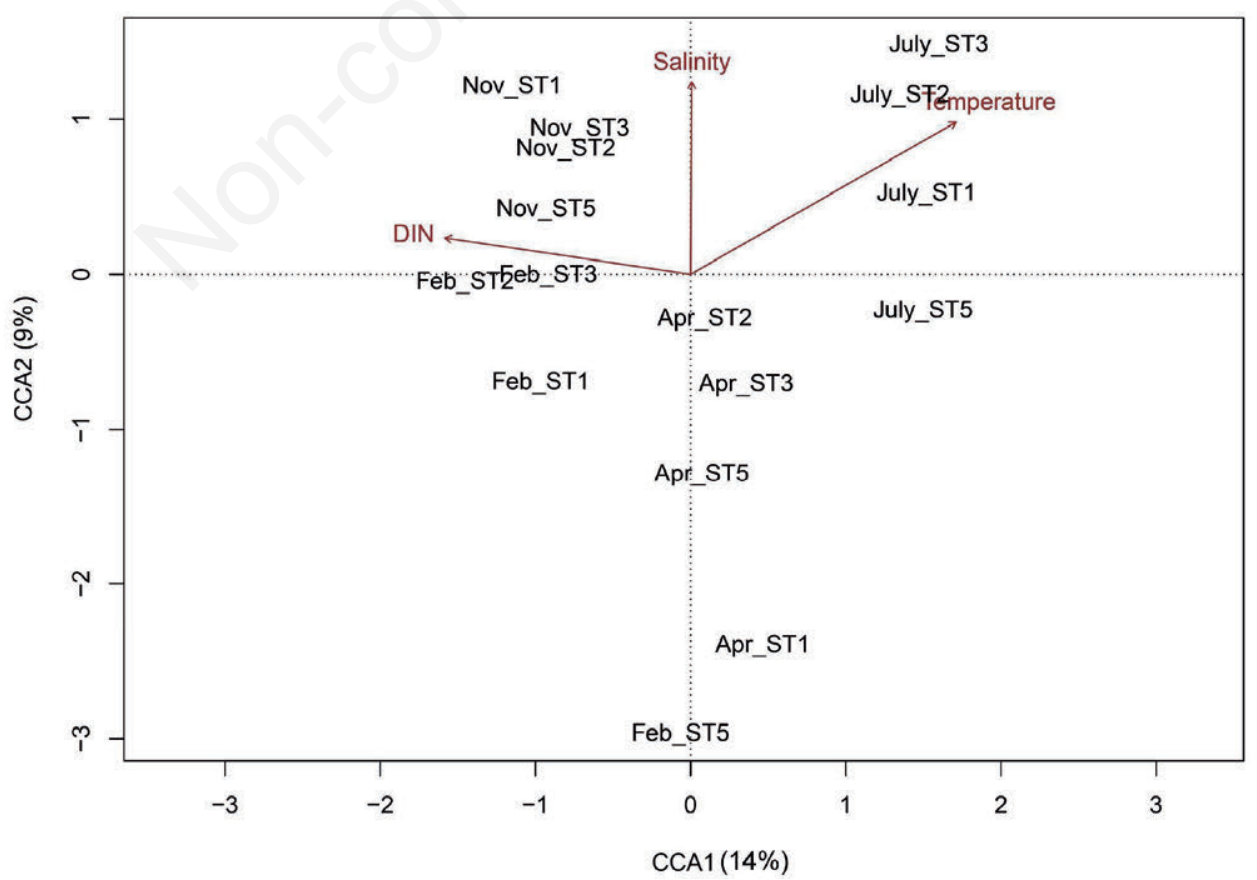

Fig. 6. Canonical Correspondence Analysis (CCA) based on the normalized dataset, with the three environmental variables selected through PerMANOVA. 
such as Teleaulax acuta, Cyclotella sp. and Minutocellus polymorphus (Sarno et al., 1993; Bérard-Therriault et al., 1999; Melo et al., 2010; Guiry and Guiry, 2019). From the diversity standpoint, spatial and temporal variations of heterotrophic, mixotrophic, parasitic such groups as Ciliophora, MAST and Syndiniales, as well as of autotrophic and heterotrophic picoeukaryotes (e.g., Trebouxiophyceae and Picozoa) emerging in this study represent an absolute novelty and hint at quite intricate and dynamic trophic interactions within the microbial food web of the lagoon.

For what concerns spatial differences, they appeared quite evident for the whole microeukaryotic communities compared to the overall homogeneity emerging from previous studies that only addressed phytoplankton. In those studies, despite some weak differences among areas, the most abundant species were shared by all stations investigated, whereby community composition appeared to be prevalently shaped by the general ecological characteristics of the lagoon ecosystem itself rather than by the specific characteristics of individual areas (Acri et al., 2004; Bernardi Aubry et al., 2004, 2013). The latter picture is based on a much higher number of observations, but the higher resolution allowed by metabarcoding may depict more effectively differences and commonalities among sites. Interestingly, some regularities in the spatial heterogeneity persisted across the sampling dates, i.e., in the coupling between Sts 1 and 5 and between Sts2 and 3, where the structure of the protist communities probably reflects different hydro-geological characteristics. Sts 2 and 3 are characterized by greater depths $(11 \mathrm{~m}$ and $4 \mathrm{~m}$, respectively) compared to Sts 1 and $5(1.5 \mathrm{~m}$ and $2.5 \mathrm{~m})$ which, being the most landward sites, are more affected by resuspended (e.g., pennate diatoms) and/or freshwaters species from the mainland than by the incoming tide from the inlets. The rather regular coupling between Sts2 and 3 may be explained by their position in the nearness of the oil tanker channel (Canale dei Petroli) that, connecting with the Malamocco inlet, is more influenced by marine waters from the Gulf of Venice. This area is characterised by higher transit time and lower residence time respect to the other two sampling stations (Guerzoni and Tagliapietra, 2006). Instead, Sts 1 and 5 are characterized by a low seabed and by a higher contribution of resuspended species (e.g., diatoms), and can be affected to varying degrees by the influence of the inland anthropogenic inputs (e.g., terrestrial waste in St1 or fresh water in St5), which are also very variable over time. This latter interpretation is confirmed by the higher abundance, at Sts2 and 3, of taxa typical of the external marine environment such as Cryptophyceae, Dinophyta, Syndiniales and MAST (Armeli Minicante et al., 2019) with respect to Sts1 and 5.

The overall protistan community variance could be related to the average environmental conditions of the sampling stations, in turn depending on the site location in the lagoon, rather than to the instantaneous measured values of the environmental variables during each sampling event, which actually explained only a minor part of the variance $(23 \%)$.

In conclusion, this HTS metabarcoding investigation reveals relatively stable spatial differences and substantial seasonal changes in the structure of the whole protistan communities of the LoV, where habitat heterogeneity and connection coexist. Protistan groups that have distinct functional roles (e.g., Ciliophora, MAST, Syndiniales and picoeukaryotes), so far never investigated in the LoV, also showed marked differences over the temporal and spatial scale, hinting at complex and dynamic relationships within the microbial community which warrant further investigations.

Overall some different hydro-geological characteristics that typify different areas contribute consistently in shaping the spatial microeukaryotic community configuration. In particular, the depth of the stations, which modulates the benthic-pelagic coupling, and the degree of relatedness with the external marine coastal environment or with the mainland, appear to play a major role in the spatial distribution of protist community within the lagoon.

\section{ACKNOWLEDGMENTS}

This work was possible thanks to partial financial support by Italy-LifeWatch-ERIC. RP was supported by the Italian MIUR Flagship project RITMARE and the European Union's Horizon 2020 Research and Innovation Program EMBRIC (GA 654008).

Corresponding author: fabrizio.bernardi@ismar.cnr.it

Key words: $18 \mathrm{~S}$ rDNA; Lagoon of Venice; transitional environments; protists plankton diversity; habitat heterogeneity; LTERItaly.

Received: 21 May 2020.

Accepted: 23 June 2020.

This work is licensed under a Creative Commons Attribution NonCommercial 4.0 License (CC BY-NC 4.0).

${ }^{\circ}$ Copyright: the Author(s), 2020

Licensee PAGEPress, Italy

Advances in Oceanography and Limnology, 2020; 11:8961

DOI: 10.4081/aiol.2020.8961

\section{REFERENCES}

Acri F, Bernardi Aubry F, Bianchi F, Boldrin A, Comaschi A, Rabitti S, Socal G, 2004. Changes in nutrients and plankton communities in the lagoon of Venice from 1970s until today. J. Mar. Sys. 51: 321-329. 
Alberighi L, Bianchi F, Cioce F, Socal G, 1992. [Osservazioni durante un bloom di Skeletonema costatum in prossimità della centrale termoelettrica ENEL di Fusina Porto-Marghera (Venezia)].[Article in Italian]. Oebalia 17:321-322.

Armeli Minicante S, Piredda R, Quero GM, Finotto S, Bernardi Aubry F, Bastianini M, Pugnetti A, Zingone A, 2019. Habitat heterogeneity and connectivity: effects on the planktonic protist community structure at two adjacent coastal sites (the Lagoon and the Gulf of Venice, Northern Adriatic Sea, Italy) revealed by metabarcoding. Front. Microbiol. 10:2736. doi: 10.3389/fmicb.2019.02736.

Basset A, Sabetta L, Fonnesu A, Mouillot D, Do Chi T, Viaroli P, Giordani G, Reizopoulou S, Abbiati M, Carrada GC, 2006. Typology in Mediterranean transitional waters: new challenges and perspectives. Aquatic Conserv: Mar. Freshw. Ecosyst. 16:441-455. doi: 10.1002/aqc.767.

Bergami C, L'Astorina A, Pugnetti P, 2018. [I cammini della rete LTER-Italia - Il racconto dell'ecologia in cammino].[Book in Italian]. CNR Edizioni, Rome; 180 pp.

Bernardi Aubry F, Berton A, Bastianini M, Socal G, Acri F, 2004. Phytoplankton succession in a coastal area of the NW Adriatic over a 10-years sampling period (1990-1999). Continent. Shelf Res. 24:97-115.

Bernardi Aubry F, Acri F, Bianchi F, Pugnetti A, 2013. Looking for patterns in the phytoplankton community of the Mediterranean microtidal Venice Lagoon: evidence from ten years of observations. Sci. Mar. 7:47-70. doi: 10.3989/scimar. 03638.21.

Bernardi Aubry F, Pugnetti A, Roselli L, Stanca E, Acri F, Finotto S, Basset A, 2017. Phytoplankton morphological traits in a nutrient-enriched, turbulent Mediterranean microtidal lagoon. J. Plankton Res. 39:564-576. doi: 10.1093/plankt/fbx008.

Cloern JE, Jassby AD, 2010. Patterns and Scales of Phytoplankton Variability in Estuarine-Coastal Ecosystems. Estuar. Coast. 33: 230. https://doi.org/10.1007/s12237-009-9195-3.

de Vargas C, Audic S, Henry N, Decelle J, Mahé F, Logares R., Lara E, Berney C, Le Bescot N, Probert I, Carmichaell M, Poulain J, Romac S, Colin S, Aury JM, Bittner L, Chaffron S, Dunthorn M, Engelen S, Flegontova O, Guidi L, Horák A, Jaillon O, Lima-Mendez G, Lukeš J, Malviya S, Morard R, Mulot M, Scalco E, Siano R, Vincent F, Zingone A, Dimier C, Picheral M, Searson S, Kandels-Lewis S, Tara Oceans Coordinators, Acinas SG, Bork P, Bowler C, Gorsky G, Grimsley N, Hingamp P, Iudicone D, Not F, Ogata H, Pesant S, Raes J, Sieracki ME, Speich S, Stemmann L, Sunagawa S, Weissenbach J, Wincker P, Karsenti E, 2015. Eukaryotic plankton diversity in the sunlit ocean. Science 348:1261605. doi: 10.1126/science.1261605.

Edgar RC, Haas BJ, Clemente JC, Quince C, Knight R. 2011, UCHIME improves sensitivity and speed of chimera detection. Bioinformatics 27:2194-2200. doi: 10.1093/bioinformatics/btr381

Elliott M, McLusky DS, 2002. The need for definitions in understanding estuaries. Estuar. Coast. Shelf Sci. 55: 815-827. doi: 10.1006/ecss.2002.1031.

European Union, 2000. Common Implementation strategy for the Water Framework Directive (2000/60/EC) - Guidance Document No 5 Transitional and Coastal Waters - Typology, Reference Conditions and Classification Systems. Office for
Official Publications of the European Communities; Luxembourg.

Ghezzo M, De Pascalis F, Umgiesser G, Zemlys P, Sigovini M, Pérez-Ruzafa CMA, 2015. Connectivity in three European coastal lagoons. Estuaries Coast. 38:1764-1781. doi: 10.1007/s12237-014-9908-0.

Gong W, Marchetti A, 2019. Estimation of 18 S gene copy number in marine eukaryotic plankton using a next-generation sequencing approach. Front. Mar. Sci. 6. doi: 10.3389/fmars. 2019.00219

Grasshoff K, Ehrhardt M., Kremling K, 1983. Methods of seawater analysis. Wiley-VCH Verlag; pp. 419. doi: 10.1002/iroh.19850700232.

Grossmann L, Jensen M, Heider D, Jost S, Glücksman E, Hartikainen H, Mahamdallie SS, Gardner M, Hoffmann D, Bass D, Boenigk J, 2016. Protistan community analysis: key findings of a large-scale molecular sampling. ISME J. 10:22692279. doi: 10.1038/ismej.2016.10.

Guerzoni S, Tagliapietra D. 2006. [Atlante della laguna. Venezia tra terra e mare].[Book in Italian]. Marsilio, Venice: 242 pp.

Guerzoni S, Rossigni P, Sarretta A, Raccanelli S, Ferrari G, Molinaroli E, 2007. POPs in the Lagoon of Venice: budgets and pathways. Chemosphere 67:1776-1785.

Holm-Hansen O, Lorenzen CJ, Holmes RW, Strickland JDH, 1965. Fluorometric determination of chlorophyll. J. Conseil Perm. Int. Explor. Mer. 30:3-15.

Horner-Devine M, Lage M, Hughes J, Bohannan BJM, 2004. A taxa-area relationship for bacteria. Nature 432:750-753. doi: 10.1038/nature03073.

Kozich JJ, Westcott SL, Baxter NT, Highlander SK, Schloss PD, 2013. Development of a dual-index sequencing strategy and curation pipeline for analyzing amplicon sequence data on the MiSeq Illumina sequencing platform. Appl. Environ. Microbiol. 79:5112-5120. doi: 10.1128/AEM.01043-13

Martiny J, Bohannan B, Brown J, Colwell RK, Fuhrman JA, Green JL, Horner-Devine MC, Kane M, Krumins JA, Kuske CR, Morin PJ, Naeem S, Ovreås L, Reysenbach AL, Smith VH, Staley JT, 2006. Microbial biogeography: putting microorganisms on the map. Nat. Rev. Microbiol. 4:102-112. doi: 10.1038/nrmicro1341.

Massana R, Gobet A, Audic S, Bass D, Bittner L, Boutte C, Chambouvet A, Christen R, Claverie JM, Decelle J, Dolan JR, Dunthorn M, Edvardsen B, Forn I, Forster D, Guillou L, Jaillon O, Kooistra WH, Logares R, Mahé F, Not F, Ogata H, Pawlowski J, Pernice MC, Probert I, Romac S, Richards T, Santini S, Shalchian-Tabrizi K, Siano R, Simon N, Stoeck T, Vaulot D, Zingone A, de Vargas C, 2015. Marine protist diversity in European coastal waters and sediments as revealed by high $\square$ throughput sequencing. Environ. Microbiol. 17:4035-4049. doi: 10.1111/1462-2920.12955

McLusky DS, Elliott M, 2007. Transitional waters: A new approach, semantics or just muddying the waters? Estuar. Coast. Shelf Sci. 71:359-363. doi: 10.1016/j.ecss.2006.08.025

Mirtl M, Borer E, Djukic I, M.Forsiusc, Haubolda H, Hugod W, Jourdane J, Lindenmayerf D, McDowellg WH, Muraokah H, Orensteini DE, Pauwd JC, Peterseila J, Shibataj H, Wohnera C, Yuk X,Haaseel P, 2018. Genesis, goals and achievements of long $\square$ term ecological research at the global scale: a critical review of ILTER and future directions. Sci. Tot. Environ. 626:1439-62. 
Oksanen J, Blanchet FG, Kindt R, Legendre P, Minchin PR, O'Hara RB, Simpson GL, Solymos P, Stevens MHH, Szoecs E, Wagner H, 2016. vegan: community ecology package, version 2.4-1. Available from: https://cran. r-project. org/web/packages/vegan/index. html

Percopo I, Ruggiero MV, Balzano S, Gourvil P, Lundholm N, Siano R, Tammilehto A, Vaulot D, Sarno D, 2016. Pseudo-nitzschia arctica sp. nov., a new cold-water cryptic Pseudo-nitzschia species within the P. pseudodelicatissima complex. J. Phycol. 52:184-99. doi: 10.1111/jpy.12395

Perin G, 1975. [L'inquinamento chimico della Laguna di Venezia, p. 47-89]. In: Cons. Depur. Acque della Z. I. Porto Marghera (ed.), [Problemi dell'inquinamento lagunare].[in Italian]. Venezia.

Piredda R, Tomasino MP, D'Erchia AM, Manzari C, Pesole G, Montresor M, Kooistra WH, Sarno D, Zingone A, 2017. Diversity and temporal patterns of planktonic protist assemblages at a Mediterranean LTER site. FEMS Microbiol. Ecol. 93. doi: 10.1093/femsec/fiw200

Piredda R, Claverie JM, Decelle J, deVargas C, Dunthorn M, Edvardsen B, Eikrem W, Forster D, Kooistra WHCF, Logares R, Massana R, Montresor M, Not F, Ogata H, Pawlowski J, Romac S, Sarno D, Stoeck T, Zingone A, 2018. Diatom diversity through HTS-metabarcoding in coastal European seas. Sci. Rep. 8:18059. doi: 10.1038/s41598-018-36345-9

Power ME, Mills LS, 1995. The keystone cops meet in Hilo. Trends Ecol. Evol. 10:182-184. doi: 10.1016/S01695347(00)89047-3

Pugnetti A, Acri F, Bernardi Aubry F, Camatti E, Cecere E, Facca C, Franzoi P, Keppel E, Lugliè A, Mistri M, Munari C, Padedda BM, Petrocelli A, Pranovi F, Pulina S, Satta CT, Sechi N, Sfriso A, Sigovini M, Tagliapietra D, Torricelli P, 2013. The Italian Long-Term Ecosystem Research (LTER-Italy) network: results, opportunities, and challenges for coastal transitional ecosystems. Trans. Wat. Bull. 7:43-63.

Quero GM, Perini L, Pesole G, Manzari C, Lionetti C, Bastianini M, Marini M, Luna GM, 2017. Seasonal rather than spatial variability drives planktonic and benthic bacterial diversity in a microtidal lagoon and the adjacent open sea. Mol. Ecol. 26:5961-5973. doi: 10.1111/mec.14363.

R Core Team, 2014. A language and environment for statistical computing. R Foundation for Statistical Computing, Vienna.

Solidoro C, Bandelj V, Bernardi Aubry F, Camatti E, Ciavatta
S, Cossarini G, Facca C, Franzoi F, Libralato S, Melaku Canu D, Pastres R, Pranovi F, Raicevich S, Socal G, Sfriso A, Sigovini M, Tagliapietra D, Torricelli P, 2010. Response of the Venice Lagoon ecosystem to natural and anthropogenic pressures over the last 50 years, p. 483-511. In: M. Kennish and H. Paerl (eds.), Coastal lagoons: Critical habitats of environmental change. CRC Press, Boca Raton.

Schloss PD, Westcott SL, Ryabin T, Hall JR, Hartmann M, Hollister EB, Lesniewski RA, Oakley BB, Parks DH, Robinson CJ, Sahl JW, Stres B, Thallinger GG, Van Horn DJ, Weber CF, 2009. Introducing mothur: open-source, platform-independent, community-supported software for describing and comparing microbial communities. Appl. Environ. Microbiol. 75:7537-7541. doi: 10.1128/AEM.01541-09

Sfriso A, Facca C, Ceoldo S, Marcomini A, 2005. Recording the occurrence of trophic level changes in the lagoon of Venice over the '90s. Environ. Int. 31:993-1001.doi: 10.1016/j.envint.2005.05.009

Sfriso A, Buosi A, 2018. Trophic status changes in the Venice Lagoon during the last 40 years. Proceedings XLIX SIBM Congress, Genoa; p. 36-39.

Socal G, Bianchi F, Alberighi L, 1999.Effects of thermal pollution and nutrient discharges on a spring phytoplankton bloom in the industrial area of the lagoon of Venice. Vie Milieu 49:19-31.

Umgiesser G, Ferrarin C, Cucco A, De Pascalis F, Bellafiore D, Ghezzo M, Bajo M, 2014. Comparative hydrodynamics of 10 Mediterranean lagoons by means of numerical modelling. J. Geophys. Res. Oceans. 119:2212-2226. doi: 10.1002/2013JC009512.

Vadrucci MR, Cabrini M, Basset A, 2007. Biovolume determination of phytoplankton guilds in transitional water ecosystems of Mediterranean Ecoregion. Transit. Waters Bull. 2: 83-102. doi: 10.1285/i1825229Xv1n2p83

Wu PF, Li DX, Kong LF, Li YY, Zhang H, Xie ZX, Lin L, Wang DZ, 2020. The diversity and biogeography of microeukaryotes in the euphotic zone of the northwestern Pacific Ocean. Sci. Total Environ. 698:134289 doi: 10.1016/j.scitotenv. 2019.134289

Zingone A, D'Alelio D, Mazzocchi MG, Montresor M, Sarno D, LTER-MC team, 2019. Time series and beyond: multifaceted plankton research at a marine Mediterranean LTER site. Nat. Cons. 34:273-310. doi: 10.3897/nature conservation.34.30789. 